\title{
THE EFFECT OF CROP RESIDUE PERCENTAGES AND THEIR CHOPPED SIZE ON SOIL COMPACTIBILITY
}

\author{
Gholamhussein SHAHGHOLI*, Abdolmajid MOINFAR \\ University of Mohaghegh Ardabili, Ardabil, Iran
}

\begin{abstract}
The advancement of technology and increasing use of mechanization in agriculture, as well as increasing size of agricultural machinery for farm capacity improvement, have led to soil compaction. In developed countries, various reports of the soil compaction impacts on the reduction of agricultural products have been provided. In developing countries, soil compaction represents a less-known issue and a its destructive nature in agriculture has not been sufficiently addressed. Furthermore, in developed countries, the soil is rich in organic matter due to conservation tillage; however, in Iran, conservation tillage is not possible to perform because of traditional agriculture and using old agricultural machinery. Therefore, plant residues are either removed from fields, or burned. However, sufficient content of organic matter in field can contribute to soil compaction mitigation. The aim of this study was to investigate the effect of percentage of crop residues and their size on soil compaction at different soil moisture contents. For these purposes, five different soil moisture contents $(8,10,12,14$ and $16 \%$ based on dry soil weight) and 4 residue rates at 3 fragmentation sizes were observed in terms of soil compaction. At all different soil moisture contents and residue sizes, with increasing percentage of added straw to the soil, the soil displacement increased. Moreover, as the straw size increased, the initial displacement during compression decreased, e.g., the maximum displacements for straw percentage of $12 \%$ and soil moisture of $8 \%$ were 64,62 and $60 \mathrm{~mm}$ considering the straw sizes of 1, 2.5 and $5 \mathrm{~cm}$, respectively. With high residue percentage, the final soil density and soil compaction were lower due to the low specific density of straw relative to soil. Furthermore, with high percentage of straw, more deformations and displacements were occurred in the mixture due to large deformation of straws. The density changes of soil-straw mixture were more significant at high residue percentages.
\end{abstract}

Keywords: bulk density; soil displacement; crop residue; soil compaction

Soil compaction represents one of the most significant destructive factors of agricultural soils. It has been shown that an increase in stress levels with higher bulk density and mechanical penetration resistance, and a decrease in soil hydraulic conductivity resulted in decreased root elongation rates and consequently prolonged the time required for roots to reach a certain soil depth (Galambošová et al., 2020). Appropriate amount of organic matter in soil is one of the factors in preventing soil compaction (Mosaddeghi et al., 2000). Soil is an elastic-plastic material. The soil elasticity increases with increasing organic matter. With existing sufficient organic matter, it is possible for soil to more or less reverse to its original state after the passage of agricultural machinery (Shahgholi and Abuali, 2015). However, to some extent, soil becomes permanently deformed due to its plastic properties. In developed countries, conservation tillage is usually used instead of traditional tillage, in which between 30 and $90 \%$ of the field is covered with crop residue (Zhang et al., 2020). These countries employ special machinery that crushes the corn grown already and distributes it to the field surface. Therefore, in these countries, the soil is rich with organic matter that improves soil structure, prevents soil compaction and improves the growth of agricultural plants.

In developing countries (including Iran), tillage machines are not fully developed, and the existing machines are not capable of conservation tillage system implementation.
Planting machines are not able to perform proper cultivation with distribution of crop residues to the field, e.g., working cultivator collects crop residues instead of loosening the soil and, after about 5 minutes of work, the blades are separated from the soil surface due to accumulation of crop residues under them. Therefore, this research intends to investigate the size of crop residue fragmentation and the effects of amount of crop remaining on field on the soil compaction. With development of tillage machines, the crushing of crop residues by installing blades in front of tines has provided a way to cultivator to operate on field and utilize the crop residues for the purposes of soil compaction reduction. Soil compaction increases the soil mechanical strength and decreases the soil fertility by reducing the nutrient and moisture content available for the plant and ultimately increases the need for fertilizers and production costs. Subsequent harmful consequences appear in the form of reduced plant growth due to less organic matter available in the culture medium, reduced nutrient and mineral cycle, reduced activity of microorganisms and increased soil degradation by machinery (Raper, 2005). According to reports, 15 million hectares of land in Eastern and Central Europe have shown medium compaction and 36 million hectares have shown high compaction level (Ferrara et al., 2015). The soil bulk density, soil sinkage, and soil strength are commonly used as characteristics of soil 
compaction (Mosaddeghi et al., 2000). Soil compaction causes the plant sensitivity to drought, inadequate ventilation, reduced water and nutrient uptake, uneven plant growth, slow germination and poorly formed root growth, and ultimately reduced yield.

It is very important to study the density and compactness of arable soils due to their negative impacts on growth and crop production. Soil compaction can reduce crop yield by up to $10 \%$ and reduce soil quality by destroying soil structure and reducing water flow in the soil (Shahgholi and Abuali, 2015). It exacerbates root diseases, such as root rot due to reduced drainage and adverse water and soil conditions (Horák et al., 2020; Pedersen et al., 2015; Allmaras et al., 1998). According to Kurjenluoma et al. (2009), tire movement under offroad conditions and rolling resistance due to soil-tire interaction lead to vertical soil compaction and horizontal soil displacement, which increases soil sinkage and soil compaction. Strategies to deal with soil compaction include controlling the soil moisture during tillage, vehicle traffic over soil, reducing the weight and pressure of vehicles in contact area with the soil, and changing soil structure by adding organic matter. The addition of organic matter has several other beneficial effects on the physical, chemical and biological properties of soil in addition to soil compaction reduction (Eifediyi et al., 2018; Ohu et al., 1994). Soil organic matter reduces the soil compaction for two reasons. Firstly, it increases the soil structure stability; furthermore, with the increment in soil organic matter, the soil elasticity also increases and the soil acts like a cushion against the applied force. Organic materials also increase the moisture range suitable for machine traffic (Ekwue and Stone, 1995). Ohu et al. (1994) reported that the use of organic matter reduced bulk density, subsidence resistance, soil shear strength. This facilitates soil management, especially in heavy (clay) soils, in which the agricultural operations are difficult to perform at high and low moisture contents. In a soil with $7 \%$ organic matter, the maximum moisture content of $52.2 \%$ was an optimum value for tillage operations, whereas with no organic matter in the same soil at the moisture

Table 1 Analysis of soil at experimental site

\begin{tabular}{|l||c|}
\hline Property & \\
\hline Sand $\mathbf{( 0 . 0 2 - 2} \mathbf{~ m m})$ & $45.66 \%$ \\
\hline Silt (0.002-0.02 $\mathbf{~ m m})$ & $29.34 \%$ \\
\hline Clay (<0.002 $\mathbf{~ m m})$ & $25 \%$ \\
\hline Organic carbon & $0.3 \%$ \\
\hline Electrical conductivity (EC) & $0.41 \mathrm{ds} \cdot \mathrm{m}^{-1}$ \\
\hline Liquid limit & $30 \%$ \\
\hline Plastic limit & $20.05 \%$ \\
\hline Field capacity (ds) & $25.13 \%$ \\
\hline Moisture content (ds) & $5.46 \%$ \\
\hline
\end{tabular}

ds - dry soil

content of $27.7 \%$, it was sensitive to agricultural operations in terms of compaction (Mosaddeghi et al., 2000). Söane (1990) observed that, by adding annual fertilizer of 0,40 and 80 tons per hectare per year for three years and applying field traffic with a contact pressure of approx. $250 \mathrm{kPa}$, the soil density in fertilized treatments was lower than in the control treatment (no organic matter).

The main aims of implementation of this research were as follows:

1. Investigation of the effects of crop residues on soil compaction and displacement during compression at different soil moisture contents.

2. Investigation of the effects of crop residue fragmentation sizes on soil compaction.

\section{Material and methods}

Experiments were performed in a soil mechanics laboratory. A $100 \mathrm{~kg}$ of farmland soil was used to prepare the samples. The usual soil texture of Ardabil provenance plain is loamy, however, for the purposes of the higher accuracy, its texture was determined by hydrometric method prior to tests, showing content of $25 \%$ clay, $29.34 \%$ silt and $45.66 \%$ sand. Since the agricultural operations were carried out under critical moisture conditions (because soil has maximum vulnerability to compaction at this moisture content and values close to it), the critical soil moisture of $22.5 \%$ was determined by performing a standard proctor test. Table 1 presents selected soil characteristics prior to testing.

The plant organic matter used in this experiment was wheat straw, which was chopped in sizes of 1, 2.5 and $5 \mathrm{~cm}$ and added to the soil evenly in different mass percentages of 4, 6, 8, 10 and $12 \%$ (Fig. 1). To chop the straw to desired size, straws were selected with the same length. Then, they were smoothened and evenly situated

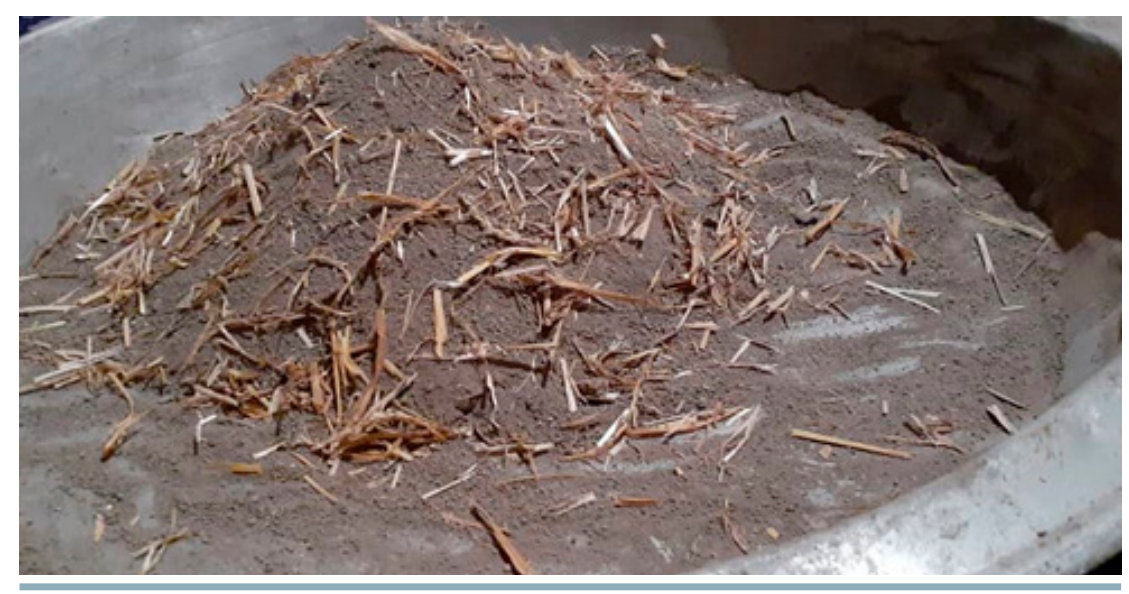

Fig. 1 Chopped straw added to the soil 


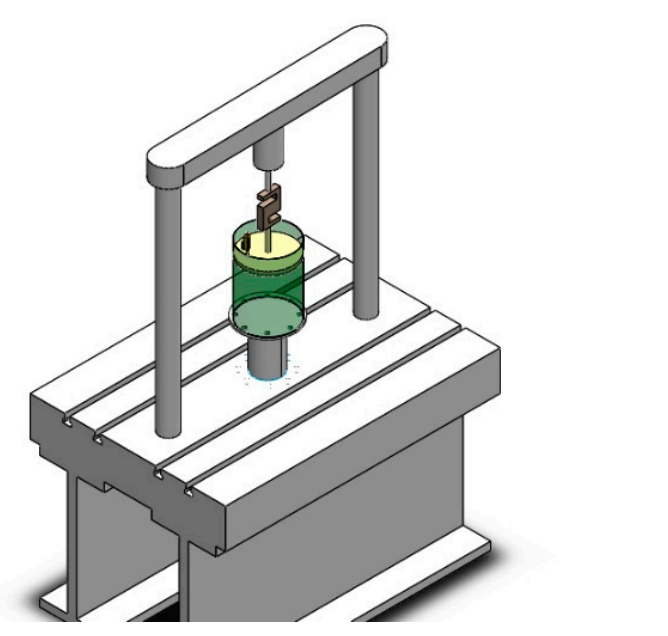

Fig. 2 Scheme of uniaxial device

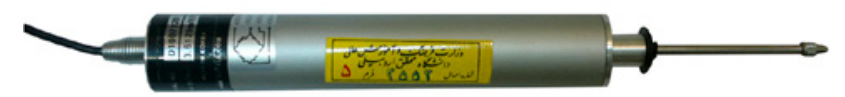

Fig. 3 Displacement transducer

on the plate. The fragmentation size was determined by measuring and marking a side edge of plat and, finally, the straws were chopped by a sharp blade based on the plate edge marks.

After reaching the desired moisture content, the samples were placed to an isolated environment for one week and covered with plastic to avoid moisture evaporation. The experiments were repeated 3 times, conducted based on factorial design and performed completely randomly. The statistical analysis was performed in Minitab 19 software. The soil bulk density was measured as an index of soil compaction.

Mixture of soil and straw at specified moisture was poured into a cylinder with $100 \mathrm{~mm}$ in diameter and $300 \mathrm{~mm}$ high. Samples were loaded at a speed of $100 \mathrm{~mm} \cdot \mathrm{min}^{-1}$ up to the maximum compressive force of $1 \mathrm{kN}$ by a uniaxial device (Fig. 2). Loading force was measure by an S type load cell with measurement capacity of $1471.5 \mathrm{~N}$ (Dacell company, Korea). The unloading was carried out at the speed of $1000 \mathrm{~mm} \cdot \mathrm{min}^{-1}$. During loading and unloading, the amount of soil displacement and reversibility was measured by a differential transducer with linear variation (model DHL-A-50, made by Korea) with the accuracy of $0.001 \mathrm{~mm}$ (Fig. 3). After measuring the final soil displacement inside cylinder, the volume of compacted soil was computed. Since the mass of straw-soil mixture was measured during filling cylinder using scales with the accuracy of $0.1 \mathrm{~g}$, the final density was obtained by dividing the mixture mass by its volume.

\section{Results and discussion}

The results of analysis of variance of data related to the bulk density change, final soil displacement, soil reversibility and final bulk density showed that the soil moisture content and straw mass percentage and straw size had a significant effect on measured parameters at a significant level of $1 \%$ (Table 2).

\section{Effects of moisture content, straw mass rate and straw size on final soil displacement}

Figure 4 shows the effects of soil moisture content, straw mass and straw fragmentation size on the final soil displacement during compaction. At all different moisture contents and straw sizes, soil displacement increased with increasing straw mass added to the soil. Moreover, the initial displacement decreased with increasing straw size, e.g., for the straw percentage of $12 \%$ and moisture content of $8 \%$, the maximum displacements of 64,62 and $60 \mathrm{~mm}$ occurred at straw size of $1,2.5$ and $5 \mathrm{~cm}$, respectively. Since the experiments were performed below the critical moisture content, the magnitude of final displacement usually decreased with increasing soil moisture content. Such behaviour indicates that the drier the soil, the greater the soil displacement (Shahgholi and Abuali, 2015). This

Table 2 Effects of independent parameters on measured parameters of soil-crop residue mixture

\begin{tabular}{|l||c|c|c|c|c|}
\hline \multirow{2}{*}{ Source } & df & \multicolumn{4}{|c|}{ Mean square } \\
\cline { 3 - 6 } & & $\begin{array}{c}\text { final soil } \\
\text { displacement }\end{array}$ & soil reversibility & bulk density & $\begin{array}{c}\text { bulk density } \\
\text { changes }\end{array}$ \\
\hline Straw size & 2 & $3670.3^{* *}$ & $50.707^{* *}$ & $54370.4^{* *}$ & $531.16^{* *}$ \\
\hline Straw mass & 4 & $11547.9^{* *}$ & $715.943^{* *}$ & $17849.5^{* *}$ & $1191.95^{* *}$ \\
\hline Moisture & 4 & $1323.0^{* *}$ & $495.998^{* *}$ & $3501.3^{* *}$ & $33.54^{* *}$ \\
\hline Straw size $\times$ straw mass & 8 & $25.1^{* *}$ & $3.053^{* *}$ & $707.9^{* *}$ & $7.79^{* *}$ \\
\hline Straw size $\times$ straw moisture & 8 & $3.3^{* *}$ & $11.925^{* *}$ & $162.7^{* *}$ & $1.71^{* *}$ \\
\hline Straw mass $\times$ moisture & 16 & $2.4^{* *}$ & $2.572^{* *}$ & $108.0^{* *}$ & $0.94^{* *}$ \\
\hline Straw size $\times$ straw mass $\times$ & 32 & $3.0^{* *}$ & $1.532^{* *}$ & $227.3^{* *}$ & $2.24^{* *}$ \\
\hline moisture & 15 & 0.1 & 0.006 & 54.7 & 0.53 \\
\hline Error & 24 & & & & 5 \\
\hline Total & & & & \\
\hline
\end{tabular}

** highly significant 
is due to its high reversibility. Additionally, during proctor test, increasing moisture content reduces the total volume and increases the density of compacted soil. Therefore, it was concluded that, with increasing moisture content, the elasticity and reversibility of the soil decreased (Mosaddeghi et al., 2000).

\section{Effects of moisture content, amount of added straw, and straw size on soil reversibility at the end of compaction}

Figure 5 shows that, at low moisture content and with increasing straw mass, the maximum reversibility occurred in the soil due to the increment in soil elasticity (Mosaddeghi et al., 2000). As the straw size increased, the reversibility decreased, which may be due to the heterogeneous distribution of large pieces of straw. At the moisture content of $8 \%$ and a straw percentage of $12 \%$, the soil reversibility
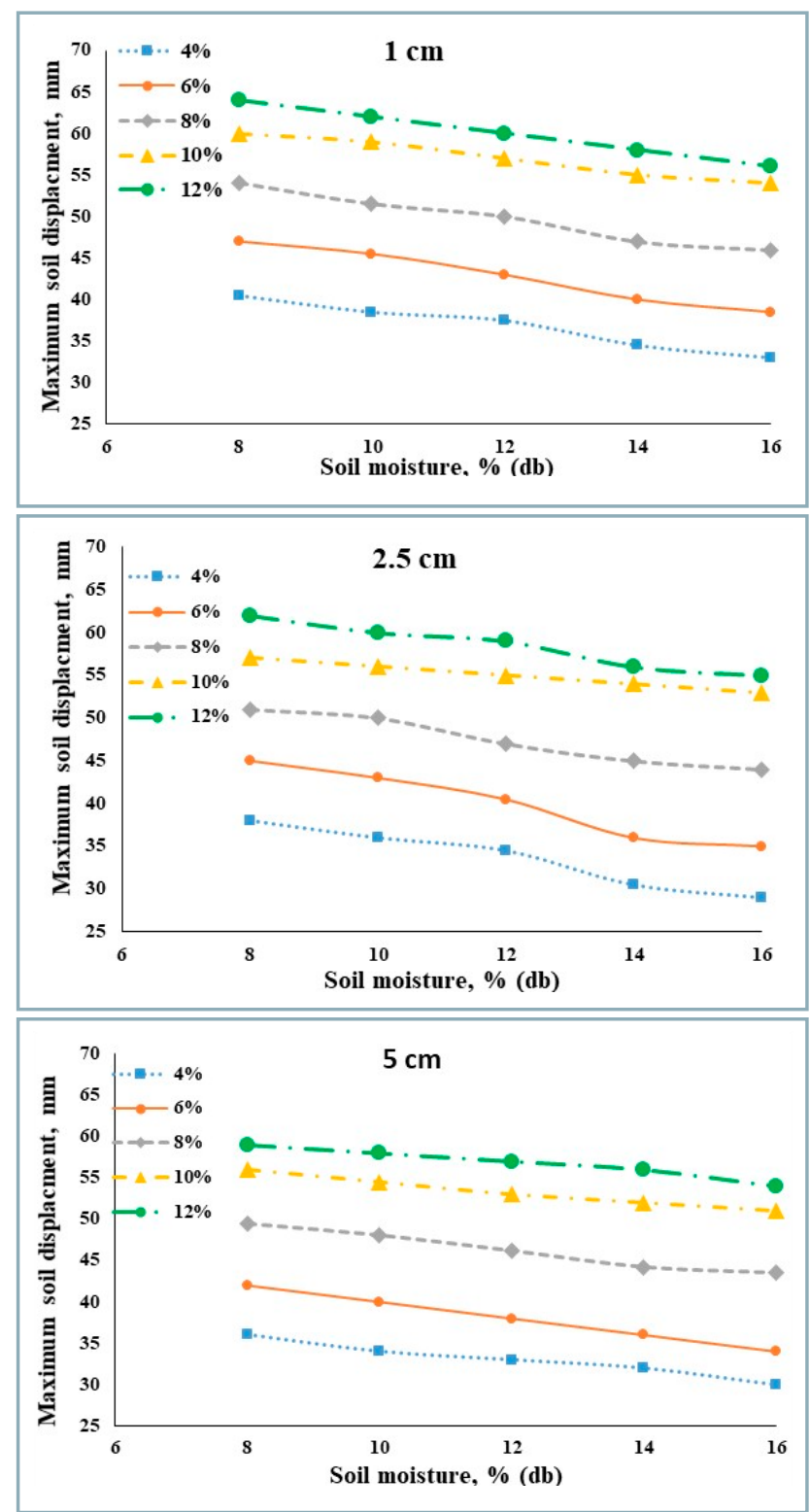

Fig. 4 Effects of size and volume of straw and soil moisture content on the soil displacement after compaction $\mathrm{db}$ shows moisture on dry soil weight base
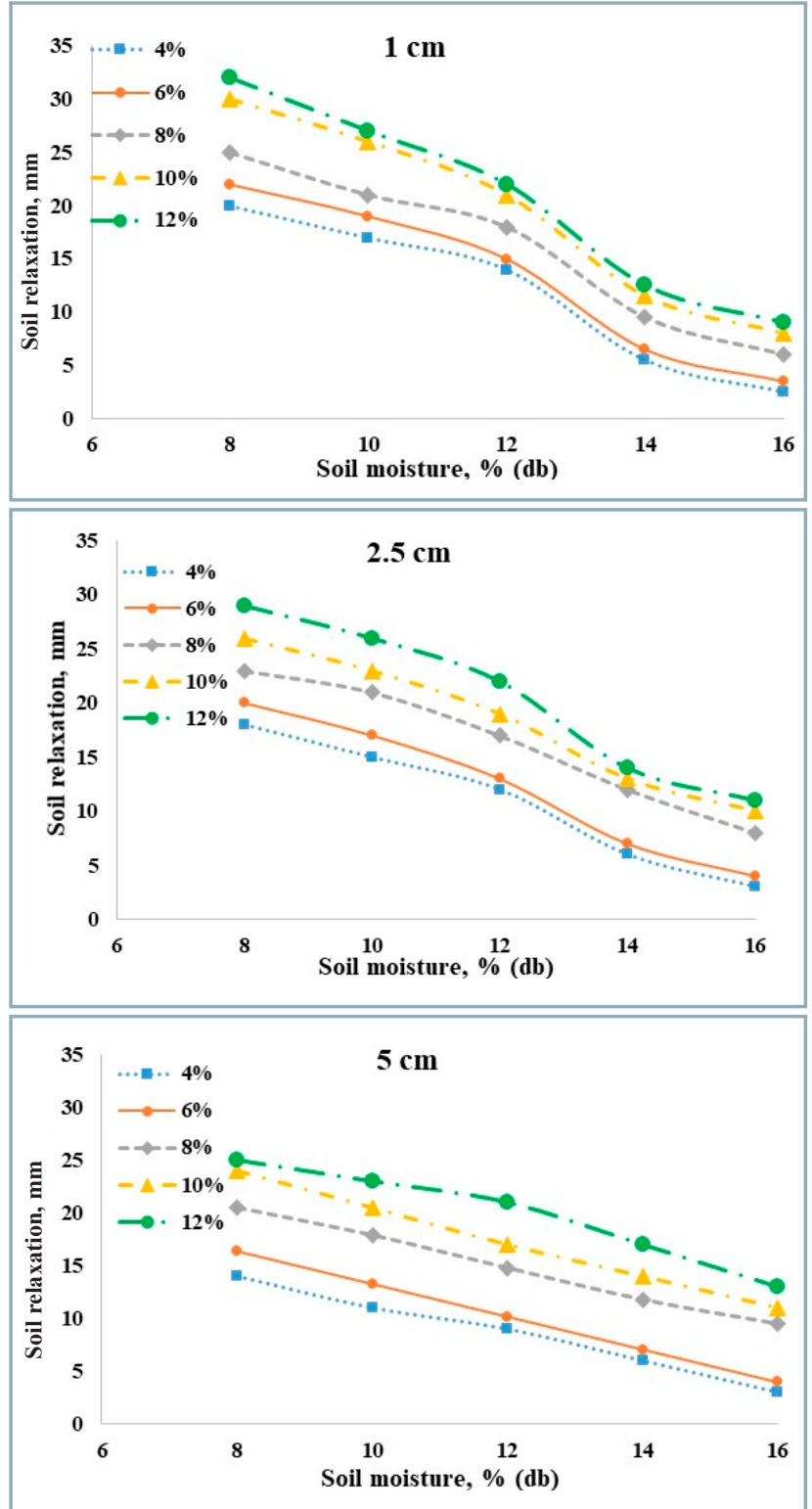

Fig. 5 Effects of size and volume of straw and soil moisture on the soil relaxation after compaction $\mathrm{db}$ shows moisture on dry soil weight base

reached 33, 29 and $25 \mathrm{~mm}$ for the sizes of $1,2.5$ and $5 \mathrm{~cm}$, respectively. At all percentages of straw and its different sizes, the soil moisture content showed the greatest effect on soil reversibility; with increasing soil moisture, the soil reversibility decreased due to increased soil adhesion. Particularly, this reduction was high at the moisture contents of 14 and $16 \%$.

\section{Effects of moisture content, amount of added straw} and straw size on the bulk density of compacted soil

Figure 6 shows the soil bulk density at the end of compaction. It was indicated that, with increasing the percentage of available straw, the final soil bulk density decreased, resulting in an increase in the soil elasticity due to the increase in adhesion of small straw particles to soil particles and the increment in adhesion properties compared to the state when the straw was of larger size and created relatively 

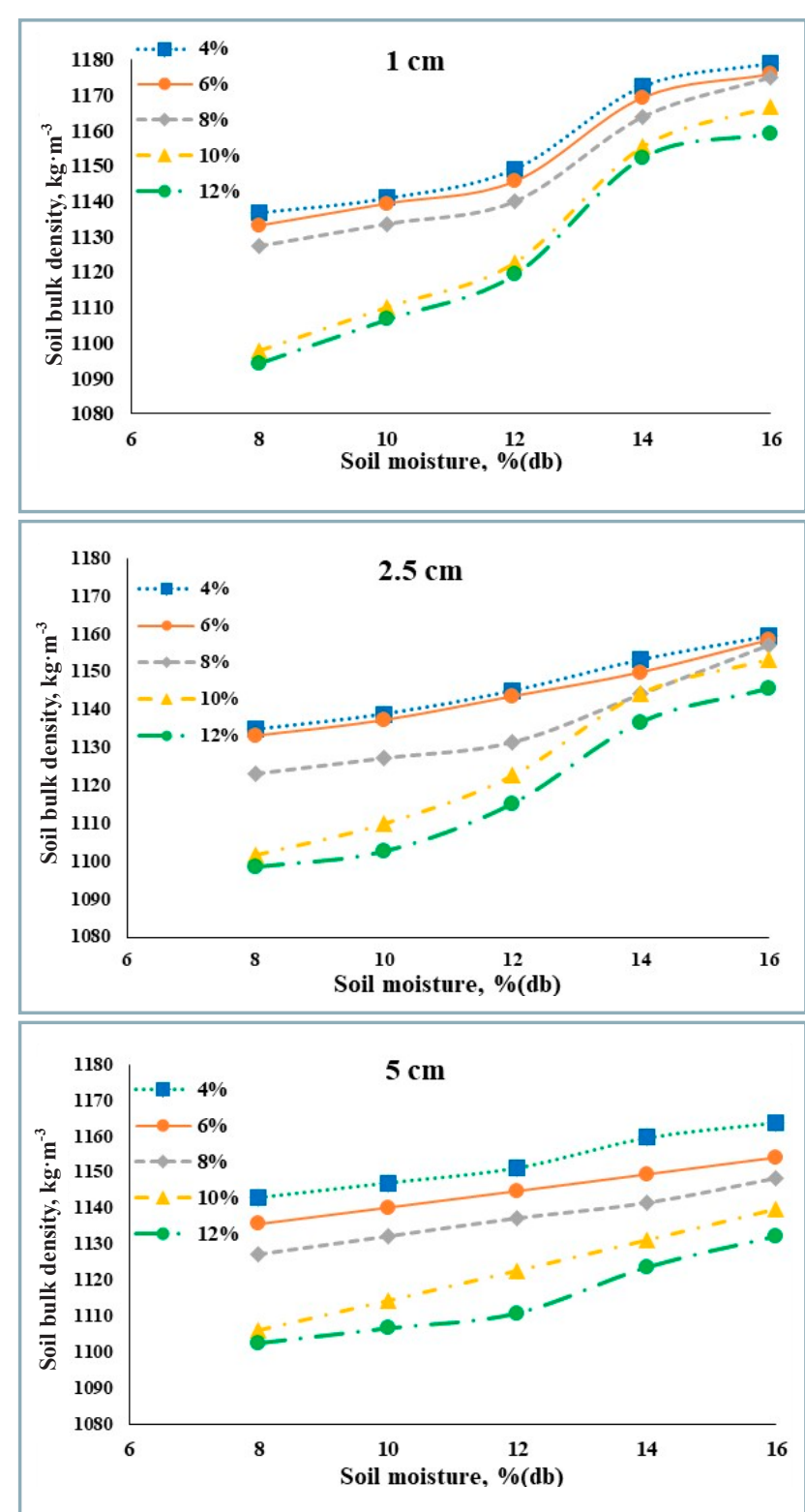

Fig. 6 Effect of size and volume of straw and soil moisture on soil bulk density

$\mathrm{db}$ shows moisture on dry soil weight base

empty spaces in the soil. As the straw size grew, the final soil density decreased, especially at high straw percentages. This was due to the increasing mixture reversibility after compaction and final density reduction of the soil-straw mixture (Ekwue and Stone, 1995). Structural degradation of soils induced by crop residue harvest is related to decreased macro-aggregation and aggregate stability (Johnson et al., 2016), which consequently lead to soil compaction (Roque et al., 2010). Tormena et al. (2016) found that crop residue harvest is associated with the soil structural degradation mainly because of lower organic matter inputs into the soil and absence of mechanical protection that disperses the pressure caused by machine traffic.

\section{Effects of moisture content, added straw rate and straw size on the bulk density variation of compacted soil}

When the straw percentage was high, the mixture bulk density values before and after compaction were lower in contrast to the lesser straw percentage due to the low specific density of the straw relative to the soil. However, when the percentage of straw was high, according to Fig. 7, numerous deformations and displacements occurred in the mixture due to the large straw deformation. For this reason, the bulk density changes in mixtures with a high straw percentage were greater. According to Fig. 7, although the bulk density was higher with high values of straw, the bulk density or final compaction were much lower in contrast to samples with no straw in the soil. Therefore, preservation conservation tillage and keeping large amounts of crop
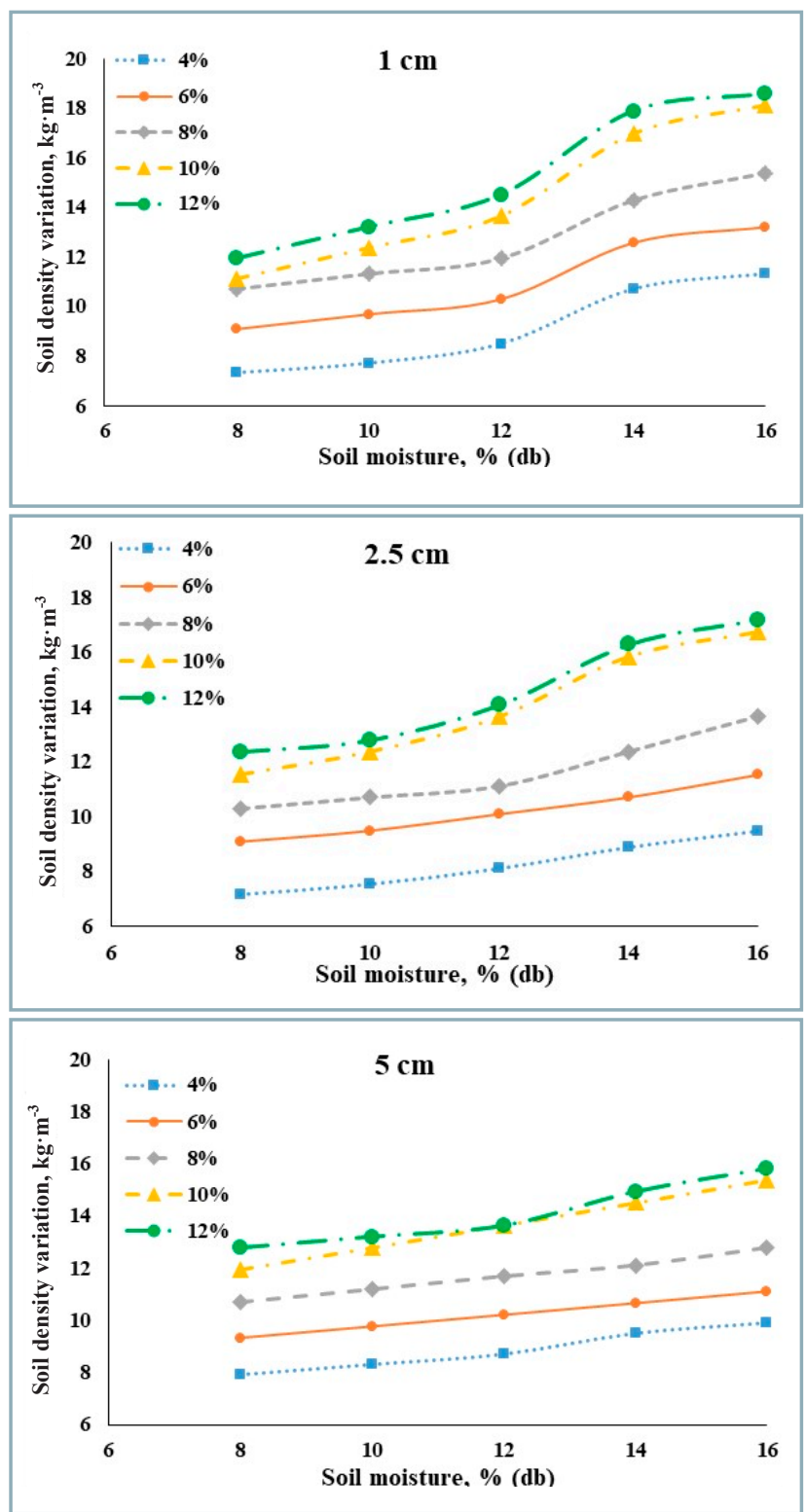

Fig. 7 Effects of size and volume of straw and moisture content on the soil bulk density variation after compaction

$\mathrm{db}$ shows moisture on dry soil weight base 
residues in field is a suitable solution to eliminate soil compaction. In all percentages of straw and its different sizes, with increasing moisture content, the bulk density of the mixture increased due to the increment in final bulk density. Almendro-Candel et al. (2020) concluded that plant residues had positive effects on preventing the soil compaction when subjected to different pressures. They found that, in a soil with initial porosity of $20 \%$, porosity was reduced to $16 \%$ after being subjected to a pressure of $224 \mathrm{kPa}$, while in mixtures with $40 \%$ of palm leaf residue, the porosity was maintained at $21 \%$.

\section{Conclusions}

1. At all different soil moisture contents and straw sizes, the soil displacement increased with increasing straw mass added to the soil. Maximum displacements $(64 \mathrm{~mm})$ were observed for the straw percentage of $12 \%$, moisture content of $8 \%$ and straw size of $1 \mathrm{~cm}$.

2. At any straw percentage and its different sizes, the soil moisture content showed the greatest effect on soil reversibility. With increasing soil moisture, soil reversibility decreased due to increased soil adhesion. The reduction was higher at relatively high moistures of 14 and $16 \%$.

3. It was concluded that with increasing added straw percentage, the final soil bulk density decreased after compression, which indicates an increase in the soil elasticity with increasing straw percentage.

4. When the percentage of straw was high, multiple deformations and displacements occurred in the mixture during compression due to the large straw deformation. For this reason, the bulk density changes for mixtures with a high straw percentage was greater in comparison to mixtures with low straw percentage.

\section{References}

ALLMARAS, R. - FRITZ, V. A. - PFLEGER, F. L. - COPELAND, S. M. 1998 Common root rot of pea (Pisum sativum L.): oat pre-crop and traffic compaction effects in fine-textured mollisols. In BOX, J. E. Root Demographics and Their Efficiencies in Sustainable Agriculture, Grasslands and Forest Ecosystems. New York : Springer, vol. 82, pp. 285-294. ISBN 9789401152709.

ALMENDRO-CANDEL, M. B. - POQUET PERLES, M. J. - GÓMEZ LUCAS, I. - NAVARRO-PEDREÑO, J. - MATAIX-SOLERA, J. 2020. Effect of the application of two plant residues on the density and porosity of soils subjected to compaction. In Spanish Journal of Soil Science, vol. 10, no. 3, pp. 233-236.

EKWUE, E. I. - STONE R. J. 1995. Organic matter effects on the strength properties of compacted agricultural soils. Transactions of the ASAE, vol. 38, no. 2, pp. 357-365.

EIFEDIYI, E. K. - KOMOLAFE, O. A. - AHAMEFULE, H. E. - FALOLA. 2018. Effect of tillage and poultry manure rates on physiological growth and yield of sesame (Sesamum indicum L.). In Scientia Agriculturae Bohemica, vol. 49, no. 4, pp. 225-266.
FERRARA, C. - BARONE, P. M. - SALVATI, L. 2015. Towards a socieconomic profile for areas vulnerable to soil compaction? A case study in a Mediterranean country. In Geoderma, vol. 247248, pp. 97-107.

GALAMBOŠOVÁ, J. - MACÁK, M. - RATAJ, V. - BARÁT, V. - MISIEWICZ, P. 2020. Determining trafficked areas using soil electrical conductivity - a pilot study. In Acta Technologica Agriculturae, vol. 23, no. 1, pp. 1-6.

HORÁK, J. - IGAZ, D. - AYDIN, E. - ŠIMANSKÝ, V. - BUCHKINA, N. BALASHOV, E. 2020. Changes in direct $\mathrm{CO}_{2}$ and $\mathrm{N}_{2} \mathrm{O}$ emissions from a loam Haplic Luvisol under conventional moldboard and reduced tillage during growing season and post-harvest period of red clover. In Journal of Hydrology and Hydromechanics, vol. 68, no. 3, pp. 271-278.

JOHNSON, J. M. F. - STROCK, J. S. - TALLAKSEN, J. E. - REESE, M. 2016. Corn stover harvest changes soil hydrology and soil aggregation. In Soil and Tillage Research, vol. 161, pp. 106-115.

KURJENLUOMA, J. - ALAKUKKU, L. - AHOKAS, J. 2009. Rolling resistance and rut formation by implement tires on tilled clay soil. In Journal of Terramechanics, vol. 46, no. 6, pp. 267-275.

MOSADDEGHI, M. R - HAJABBASI, M. A. - HEMMAT, A. - MAJID, A. 2000. Soil compactibility as affected by soil moisture content and farmyard manure in central Iran. In Soil and Tillage Research, vol. 55, no. 1, pp. 87-97.

OHU, J. O. - EKWUE, E. I. - FOLORUNSO, O. A. 1994. The effect of addition of organic matter on the compaction of a Vertisol from northern Nigeria. In Soil Technology, vol. 7, no. 2. pp. 155-162.

PEDERSEN, H. H. - SØRENSEN, C. A. G. - OUDSHOORN, F. W. KROGSGARD, P. - MUNKHOLM, L. J. 2015. Evaluation of onion production on sandy soils by use of reduced tillage and controlled traffic farming with wide span tractors. In Acta Technologica Agriculture, vol. 18, no. 3, pp. 74-82.

RAPER, R. L. 2005. Agricultural traffic impacts on soil. In Journal of Terramechanics, vol. 42, no. 3, pp. 259-280.

ROQUE, A. A. O. - SOUZA, Z. M. - BARBOSA, R. S. - SOUZA, G. S. 2010. Agricultural traffic control and soil physical attributes in sugarcane areas. In Pesquisa Agropecuária Brasileira, vol. 45, pp.744-750 (In Portuguese: Controle de tráfego agrícola e atributos físicos do solo em área cultivada com cana-de-açúcar).

SHAHGHOLI, G. - ABUALI, M. 2015. Measuring soil compaction and soil behavior under the tractor tire using strain transducer. In Journal of Terramechanics, vol. 59, pp. 19-25.

SÖANE, B. D. 1990. The role of organic matter in soil compactibility. A review of some practical aspects. In Soil and Tillage Research, vol. 16, no. 1-2, pp. 179-201.

TORMENA, C. A. - KAREN, D. L. - LOGSDON, S. D. - CHERUBIN, M. R. 2016. Visual soil structure effects of tillage and corn stover harvest in lowa. In Soil Science Society of America Journal, vol. 80, no. 3, pp. 720-726.

ZHANG, J. - WANG, J. - WANG, P. - GUO, T. 2020. Effect of no-tillage and tillage systems on melon (Cucumis melo L.) yield, nutrient uptake and microbial community structures in greenhouse soils. In Folia Horticulturae, vol. 32, no. 2, pp. 265-278. 